\title{
Smileys Without Borders: A Critique of Transboundary Inter- action between Politicians, Journalists and PR Practitioners on Social Media
}

\author{
Peter Berglez
}

School of Education and Communication, Jönköping University, Jönköping, Sweden, peter.berglez@ju.se

\begin{abstract}
The purpose of this article is to contribute a critical theoretical understanding of cross-professional relations on social media, focusing on politicians, journalists and PR practitioners. It is well known that these professional groups establish personal and close relations in offline contexts, but more attention needs to be paid to the role of social media. Here, it is argued that in the context of digital media use, semi-private chatting, humour, and mutual acknowledgement, including the use of likes, smileys, heart symbols, etc., are evidence of a 'neoliberalisation' of cross-professional relations. The underlying idea is that the common practice of self-branding undermines representations of professional belonging and exacerbates the blurring of professional boundaries. The critical conceptualisation of such 'transboundary' interaction between politicians, journalists and PR practitioners, which is guided by a culturalmaterialist approach, includes the presentation of examples deriving from the Swedish Twittersphere, and suggestions for empirical research.
\end{abstract}

Keywords: Politicians, Journalists, PR Practitioners, Social Media, Cross-Professional Relations, Twitter, Transboundary Interaction, Critical Theory, Neoliberalized Logics, Individualization, Flexibilization, Churnalism.

Acknowledgements: This work was supported by the Swedish Research Council (Vetenskapsrådet). I would like to thank the two reviewers, Marko Ampuja and an anonymous scholar, for their relevant and useful comments on a previous version of this paper. I'm also grateful to Ulrika Olausson and Sean Phelan for their careful reading of the manuscript and insightful suggestions for improvement.

\section{Introduction}

In many countries, politicians, journalists and PR practitioners are becoming ever more "inextricably linked" (Lewis et al. 2008, 2), thereby contributing to a convergent (Deuze 2007) and hybrid (Chadwick 2013) communication sector. The primary causes of this development might vary from nation to nation. Common important factors are the power balance between the public and private sectors (Garsten et al. 2015), the character of the media sector/system (Hallin and Mancini 2004) and/or the political culture (Schohaus et al. 2016, 4-5). In Sweden, which will serve as a national example in this article, the expansion of commercial media, media management, and the PR industry (Garsten et al. 2015) in recent decades has led to fewer barriers between politics, media and PR in the workforce. In Sweden, but also elsewhere (O'Donnell et al. 2016; Macnamara 2016, 133), many unemployed or freelancing journalists, as well as politicians, are increasingly finding the PR business a lucrative option and therefore migrate to the commercial sector (Tyllström 2010), but the traffic might also go in the other direction (Allern 2011; Garsten et al. 2015). A growing number of professionals with 
'ex'-prefixes are becoming important agents of convergence culture, be they ex-journalists, now active in PR; ex-PR practitioners, now active in politics; or 'both/and' practitioners who are active in several fields simultaneously. The latter might involve freelancers doing both traditional journalism and PR, or communication consultants working both for a political party/organisation and a PR firm.

A possible positive consequence of this development is the increasing number of 'reflexive' professionals who have the ability to understand 'the other side' and possess large networks. Simultaneously, from a democratic point of view, there is a need to problematise the deepening of social ties across professional fields and its undermining of boundary work (Revers 2014; cf. Chadwick and Collister 2014), i.e. articulations of difference and distance between the professional fields. The stronger the social companionship between actors in politics, media and PR, the thinner the line between professional and unprofessional behaviour (Revers 2014) in which the relations might become "too cozy" (Lewis et al. 2008, 2). Democratically speaking, what is at stake is the maintenance of each profession's unique duties or roles in society. This maintenance involves the following forms of boundary work:

- The boundaries between politicians and journalists: To be able to do their jobs properly, these two professional groups need to engage in collaboration (Davis 2009) often described as the source - journalist relationship (Gans 1979). But as politicians and journalists both aspire to the badge of foremost representatives of democracy as well as of the public, they must sustain the "tug of war" (Ibid.) by standing in opposite corners of the ring. Otherwise, their relations might appear like a joint (elite) culture and too much of a buddy system (Berglez 2016).

- The boundaries between politicians and PR practitioners: in the current times of extreme mediatisation and quick results, politicians are increasingly dependent on PR advice and PR campaigns. But to be able to uphold the democratic dialogue with the grassroots, they also need to signal their distance from PR practitioners who are recruited from or interwoven with the private sector and thus affiliated with divergent corporate interests (Garsten et al. 2015).

- The boundaries between journalists and PR practitioners: Due to the business crisis in the media sector, media houses, including their editors and journalists, become increasingly dependent on material and pitches from PR firms, which is paving the way for "churnalism", content based on combinations of editorial and PR-based material (Lewis et al. 2008; Jackson and Moloney 2016). However, to obtain credibility in the eyes of the media consumers, and to continue to be associated with 'homemade' editorial content, journalists need to articulate professional autonomy and distance towards PR practitioners (Macnamara 2016).

From a historical perspective, the blurring of boundaries between politics, media and PR is not a novel phenomenon. Recall, for example, the final section of Habermas's (1962/1989) book The Structural Transformation of the Public Sphere: An Inquiry into a Category of Bourgeois Society, which describes the rise of mass society and mass commercialism at the beginning of the previous century as to a great extent associated with the development as well as the implosion of a communicative politics-media-PR triad. Nevertheless, it is relevant to continually return to this new old problem, as the conditions could always worsen in terms of increased blurring of professional boundaries. 


\subsection{The Focus of this Article}

An important assumption is that the interaction between these three professional fields is considered in relation to the media-technological development in society. In this article, the particular role of social media in accelerating and deepening social ties across professional boundaries is analytically examined. There is a need for scholarly work that pays attention to how social media, where the above-mentioned team-switching phenomenon (or culture) is highly visible, brings politicians, journalists and PR practitioners ever closer. While, for example, Vobič et al. (2016) and Waters et al. (2010) focus on cross-border activities in a more traditional sense, primarily analysing digital exchanges of a strictly work-oriented kind, this contribution instead intends to concentrate on the overlapping sociability dimension and how the use of digital communication tools exacerbates "socially integrated relations" across professional fields (Davis 2009, 210). In offline contexts, such relations are associated with "going for drinks and dinners" (Revers 2014, 48) with actors from the 'other side', or developing friendships across professional borders. Due to the democratic importance of boundary-drawing practices among representatives of politics, journalists and PR, a critical theoretical perspective (Fuchs 2014a, 2014b; Marwick 2013) is needed. To be more precise, what will be focused on is how the "socially integrated relations" become part of social media's "neoliberalized" logics (Phelan 2014). It will be argued that cross-professional intermingling on social media tends to reinforce an individualisation and flexibilisation of professional belonging, as well as of the very meaning of "being professional" (cf. Ekman and Widholm 2015; Hedman 2015; Olausson 2017). In this context, network theory's optimistic understanding of digital media (Castells 2009; Cardoso 2012), which is often applied in social media research, needs to be contrasted with cultural materialist notions of the neo-Marxian kind (Williams 1980; Fuchs 2017), which instead pay attention to how symbolic articulations/exchanges at the micro-level, such as everyday interactions on social media, are dialectically intertwined with (capitalism-driven) material and economic developments at the meso and macro levels of society (Fairclough 1995; 2009; Phelan 2014; cf. Berglez 2006).

The purpose is thus to contribute a critical theoretical understanding of cross-professional relations on social media involving politicians, journalists and PR practitioners. More precisely, the contribution lies in theorising what will be referred to as transboundary interaction, ${ }^{1}$ i.e. the practicing of "socially integrated relations" that, in contrast to boundary work, testify to a weakening of professional boundaries. First, the intention is to focus on how transboundary interaction is shaped by existing sociotechnological conventions in the use of social media. This is complemented with detailed examples of how Swedish politicians, journalists and PR practitioners go 'transboundary', centred around semi-private exchanges, humour and mutual acknowledgement. Thereafter follows a critical theorisation of how the transboundary interaction is embedded in economic and material (neoliberal) processes in society, and its potential consequences for the relations between politics, journalism and PR in the longer term. The article concludes with a section focusing on the usefulness of the concept of transboundary interaction for empirical research.

\footnotetext{
${ }^{1}$ At the same time, social media tends to generate new forms of professional distinctions and boundaries, for example between those journalists/politicians/PR-practitioners who use social media in their everyday work, and those who don't (see Hedman and Djerf-Pierre 2013); or between professionals on social media endowed with high status/power and those lower down in the hierarchy (Marwick 2013; Berglez 2016)
} 
Finally, the emphasis on politicians, journalists and PR practitioners does not exclude the possibility of paying analytical attention to the ways in which these three professional groups, in their everyday work and in different networked contexts, communicate with other professional groups, be they academics, policy professionals or digital entrepreneurs. In this context, politicians, journalists and PR practitioners have been selected because they and their relations can be said to represent the core of society's communication sector, which is the theoretical focus of this contribution.

\section{How Transboundary Interaction is Embedded in Socio-Technological Conven- tions of Everyday Use of Social Media: Some Examples}

A considerable number of studies show that the relations between politicians, journalists and PR practitioners are characterised by practices and patterns of sociability. For example, despite the inbuilt "tug-of-war" rationale (Gans 1979) of the politician-journalist relationship, it is also "human" (Revers 2014, 46), involving "personal relations" and "love-hate" relationships (Davis 2009, 209-210), "tango" (Gans 1979; Strömbäck and Nord 2006), mutual "trust" (Larsson 2002) and cultural identification (Berglez 2016). Furthermore, despite journalists' inbuilt hostility towards PR practitioners (Fredriksson and Johansson 2014), their relationship might also be a "close" one (Schohaus et al. 2016, 2; cf. Waters et al. 2010), in which the two parties are hardly "strange bedfellows" (Macnamara 2016, 119). The most consensual relations among politicians and PR practitioners are probably to be found in cases when the former recruit the latter for strategic advice and/or campaigning (Garsten et al. 2015). However, what is suggested here is that the offline intermingling practiced in lobbies, workshops, press conferences, events, political festivals (Wendt 2012; Östberg 2013), and so forth is not only increasingly being transferred to social media, but that digital technology can potentially make it flourish. In this respect, what facilitates relaxed socialising across professional borders is social media's collapse of professional/public and private/personal contexts (Marwick and boyd 2011):

On social media [...] we act in various roles (as friends, citizens, consumers, workers, colleagues, fans etc.), but all of these roles become mapped onto single social media-profiles that are observed by different people that are associated with our different social roles. This means that social media like Facebook [or Twitter] are social spaces in which social roles tend to converge and become integrated in single profiles (Fuchs 2014b, 77).

Social media communication, including the transboundary kind of interaction, tends to intensify practices of impression management in which users are seeking to make a positive impression on others (Papacharissi 2011). The "integrated single profile" mentioned by Fuchs above is an idealised one, chiselled out through the strategic and creative use of discourses, genres and styles (Berglez 2016). Discourse, i.e. "a particular way of constructing a particular (domain of) social practice" (Fairclough 1995, 76) involves, for example, the articulation of professional, lay, economic, political, commercial, popular, or educational discourses; genre concerns "semiotic ways of acting and interacting" (Fairclough 2009, 164) such as chatting, debating, making small-talk, storytelling, providing infotainment, etc.; while styles are more detailed accounts of how various genres and discourses become "realized" through a humorous, formal, informal, ironic, etc. style (lbid.). Below, transboundary interaction and its application of 
discourses/genres/styles will be exemplified ${ }^{2}$ with material deriving from the Swedish Twittersphere ${ }^{3}$. Three conventional forms of social media interaction will be presented, namely semi-private exchange, humour, and mutual acknowledgement. The examples include different cross-professional constellations; more precisely journalist - PR practitioner, politician - journalist; politician - PR practitioner, or all three professional fields represented simultaneously.

\subsection{Transboundary Interaction and Semi-Private Exchanges}

Semi-private exchanges involve private (but not entirely private) discourse characterised by a personal style of tweeting. In the first example, PR practitioner Jonas Morian (@promemorian), an ex-journalist with previous connections to politics and the Social Democratic Party, is congratulated on his birthday by his spouse (@stinamorian) who herself has a background as both a politician and journalist:

Tweet from @stinamorian:

Today @promemorian turns 44. Hurray for my husband today! [23 February 2016]

Tweet from @promemorian:

A glamorous start to the birthday celebrations @Stockholm-Arlanda Airport Terminal 5. [Link to Instagram photo]

This, in turn, renders congratulations from different directions:

Tweet from: @MatsAosv (Undersecretary in the Social Democratic Party):

Congratulations!

2 The examples from the Swedish Twitter sphere derive from different samples, which have been collected on different occasions during 2015-2017 for the research project The Journalism-Politics-PR Interplay on Twitter: Hybridized, Cross-Professional Relations on the Web, funded by the Swedish Research Council. As this is not an empirical study, the examples presented do not represent the users' activities on Twitter in a more general sense. Thus, in this article, the selected users appear only in order to exemplify the different forms of transboundary interaction. The tweets and Twitter conversations have been translated from Swedish to English.

${ }^{3}$ Thus, the social media site discussed in this article is Twitter, which is used for writing short, text-based messages (tweets) and forwarding (retweeting) others' tweets. With more than 300 million monthly users worldwide, Twitter has become a central digital tool for professionals, not least in the broad communication sector. It is an open, public network that allows users to make connections with (i.e. follow) whomever they want, with each tweet being restricted to 140 characters. An exchange between two or more users might generate longer threads, but shorter exchanges of 3-6 tweets, or very micro-oriented communication with only two tweets (one initial tweet and one reply) seem to be more common. The very limited forms of interaction might generate misunderstandings, thereby exacerbating polarisation and antagonism (e.g. Yardi and boyd 2010), but this does not exclude the possibility of very consensus-oriented interaction (Berglez 2016). 
Tweet from: @NiklasNrdstrm (Councillor in Luleå municipality, former leader of SSU, the youth section of the Social Democratic Party, and former PR consultant):

Congratulations old friend

Tweet from: @AlexVoronov (journalist and political editor at the liberal newspaper Eskilstuna-Kuriren):

Congratulations @promemorian!

Tweet from @Carolindahlman (political editor at the liberal newspaper Kristianstadsbladet and also PR consultant and communication expert):

HURRAY for you today

The above congratulations are all in accordance with conventional social media behavior, in which users with social ties text nice things to each other. However, as the congratulatory acts primarily derive from a networked, elite-oriented assemblage (Reese 2016), what crystallises is the overlapping and converging conditions of the Swedish communication sector, in which professionals in politics, journalism and PR appear as an informal joint culture/group. Personal exchanges about professional life, especially those generating identification across professional fields, might give a similar impression. The below example resembles a chat at a bar after work between the ex-politician and former Press Secretary of the Conservative Party, @kentpersson, who is now working for the global PR and communication firm Burson-Marsteller, and @hannaolsson, a news editor of the leftist tabloid Aftonbladet:

Tweet from @hannaolsson:

There's a Springsteen documentary in Agenda's time slot. Now that's what I call knowing your audience. [Agenda is a weekly political TV show on SVT (Swedish Public Service television), traditionally broadcast on Sunday evenings at 9 o'clock] [27 March 2016]

Reply from @kentpersson:

@hannaolsson easy choice :) it'll be to watch the Boss :)

The remaining conversation:

@kentpersson Agenda's being preempted, so you won't miss anything :)

@hannaolsson All the better. I'm so on top of things nowadays :)

@kentpersson Sounds great

Although they represent contrasting professions and different ideological/political 'camps', they share an interest in the TV program Agenda, an essential source of information for both an ex-politician/PR-practitioner and a news editor, and have a point of mutual identification in the various tribulations of professional life. The latter is demonstrated above through @kentpersson's implicit discovery that, since leaving politics for the PR sector, he no longer keeps an eye on certain things, such as the fact 
that Agenda was preempted on TV, thus indicating that nowadays he lives a less stressful life. He never actually intended to watch Agenda, preferring instead the documentary about Bruce Springsteen ["easy choice :) it'll be to watch the Boss :)"] which is replied to with a sympathetic "Sounds great".

\subsection{Transboundary Interaction and Humour}

In a pioneering study of humour on Twitter, journalists were to a great extent found to be "'trying to be funny' - making humor one of the most common forms of Twitter use" (Holton and Lewis 2011, 12). This result could probably be applied to other professional groups as well, making humour, which is assumed to attract more followers and create a larger network, a common way of communicating across professional fields as well. In the first example, Oisín Cantwell (@osinincantwell), reporter at Aftonbladet, exchanges 'funny' tweets with PR practitioner Carl Melin (@CarlMelin) about dressing styles, in which the humour seems to consist of inside jokes ("your aesthetics limit you", etc.)

\begin{tabular}{|l|l|}
\hline $\begin{array}{l}\text { Do I dare buy a shirt with pattern consisting of } \\
\text { beautiful birds? Note, am pathologically con- } \\
\text { servative when it comes to clothing. 11 March } \\
2017\end{array}$ & Opening tweet by @osinincantwell. \\
\hline $\begin{array}{l}\text { @osinincantwell a shirt should be light blue, } \\
\text { white, or blue-and-white striped. Anything else } \\
\text { is an abomination (or casual shirts, like Hawai- } \\
\text { ian) }\end{array}$ & Reply from @CarlMelin \\
\hline @CarlMelin your aesthetics limit you & Reply from @osinincantwell \\
\hline $\begin{array}{l}\text { @osinincantwell no my conservatism reflects } \\
\text { well upon me }\end{array}$ & Reply from @CarlMelin \\
\hline $\begin{array}{l}\text { @CarlMelin You're confusing conservatism } \\
\text { with lack of imagination. Not an entirely un- } \\
\text { common syndrome. }\end{array}$ & $\begin{array}{l}\text { End of exchange, which concludes with an ob- } \\
\text { ligatory "like" from @CarlMelin }\end{array}$ \\
\hline
\end{tabular}

Table 1: Transboundary interaction and humour

This kind of "cross-border" humour seems like a way to occasionally "ease the pressure" and distance oneself from professional roles and obligations, as well as to amuse a Twitter "audience" (Crawford 2009). The genre, which could be termed "homemade infotainment", might include visual elements, with the users publishing and commenting on photos. The below example begins with a tweet from @Johanlngero, formerly a Press Secretary for the Christian Democratic Party, but now strategic communicator for the centre-right think-tank Timbro. The tweet contains a comment about a news magazine cover, which is included in the message, depicting the Director of SÄPO (the Swedish secret police), Anders Thornberg, hidden beneath a couch. It is quite obvious that what makes the photo hilarious is that Thornberg, a person with a serious demeanour and position in society, is placed in a very unexpected location, and that he accepts being made to look ridiculous.

@JohanIngero:

Excuse me, but how the heck could SÄPO agree to a photograph like this? [4 March 2016]

The tweet is soon followed by another 'awkward' photo, published by @TomasRamberg, a leading domestic reporter at SR (Swedish Radio). It shows the former political 
leader of the Swedish Centre Party, Olof Johansson, in a similarly unexpected and humorous situation, more precisely walking knee-deep in the sea, wearing a suit and carrying a briefcase. The photo, originally from 1991, was intended to represent Johansson and his political party as marking a watershed in Swedish politics, but was instead viewed as a desperate bid for publicity:

@TomasRamberg:

If Olof Johansson could agree to this, then...

@Johanlngero's reply humorously refers to Johansson's retirement from politics:

@TomasRamberg He disappeared shortly after...

This exchange is followed by journalist @TomasRamberg's publishing of two more photos depicting two former leaders of the Christian Democrats, Alf Svensson and Göran Hägglund (@goranhagglund), dressed in swimming trunks on the beach, the latter clearly serving as a comical follow-up to the former. The photo of Hägglund is explicitly addressed to PR practitioner @JohanIngero, who once worked as Göran Hägglund's Press Secretary, leading to an ironic discussion about the photo's promotional value.

Tweet from @TomasRamberg:

@JohanIngero I can hear from your tone that you're the one who sold them on the idea

The photos then give rise to a playful chat about who is most physically fit and the difficulty of staying in shape, with new conversation participants dropping in, also from outside the politics-journalism-PR domain. After a while, @goranhagglund himself, who is now a PR consultant and thus an ex-politician, delivers the following good-natured tweet:

@TomasRamberg @JohanIngero @LidmanLidman Alright then, let's get back to work!

The above tweets, not least the one by @goranhagglund, give the impression of a virtual shared office space, transcending central Stockholm's different media houses, PR agencies, political headquarters, and so on, thus breaking drown their institutional walls and allowing for funny messages and exchanges across professional borders.

\subsection{Transboundary Interaction and Mutual Acknowledgement}

A widespread feature of Twitter and other social media is mutual acknowledgement, in the sense of making positive comments about other professionals' actions. Acting generously toward others is potentially good for one's reputation, and might serve strategic interests in terms of relationship management and network building. The two tweets below exemplify the very conventional way of delivering acknowledgement across professional borders. Journalist @miaodabas, known for moderating political web seminars about different topics, receives praise from PR practitioner and ex-journalist @paulronge (first tweet) and ex-Political Secretary of the Conservative Party and PR practitioner @kentpersson (second tweet): 
$@$ MiaOdabas super sharp and very interesting. You really capture the issues of the day! [17 December 2015]

Starting the day with \#smartasamtal where brilliant @miaodabas is leading the discussion [29 January 2016]

The next example begins with journalist Patrik Oksanen retweeting a tweet about himself. The original tweet contains news about his receiving a prestigious prize. In the retweet, he adds some text himself, giving thanks for all the congratulations. This prompts more congratulations from different directions, including one from the leader of the Swedish Center Party, Annie Lööf:

\begin{tabular}{|c|c|}
\hline $\begin{array}{l}\text { A fabulously enjoyable evening Thanks for } \\
\text { all the congratulations } 9 \text { March } 2017 \\
\text { Retweet: @DagensOpinion The award for Ed- } \\
\text { itorial Writer of the Year goes to Patrik } \\
\text { Oksanen, political editor at [the newspaper] } \\
\text { Hudiksvalls Tidning and editorial writer for } \\
\text { [online media company] Mittmedia. }\end{array}$ & $\begin{array}{l}\text { Patrik Oksanen's (@patrikoksanen) tweet } \\
\text { about the prize ceremony and following party, } \\
\text { is embedded in a retweet of news magazine } \\
\text { @DagensOpinion's tweet about his award. }\end{array}$ \\
\hline $\begin{array}{l}\text { @patrikoksanen Extremely well-deserved. } \\
\text { Warmest congratulations to Sweden's sharp- } \\
\text { est pen and penetrating analysis and investi- } \\
\text { gation! }\end{array}$ & $\begin{array}{l}\text { Congratulatory tweet to Patrik Oksanen from } \\
\text { politician Annie Lööf (@annieloof), praising } \\
\text { Oksanen's qualities as a journalist in superla- } \\
\text { tive terms. }\end{array}$ \\
\hline @annieloof Thanks! & $\begin{array}{l}\text { Reply from Oksanen, which in turn is liked [:- } \\
\text { )]by Annie Lööf. }\end{array}$ \\
\hline
\end{tabular}

Table 2: Transboundary interaction and mutual acknowledgement

Mutual acknowledgement across professional fields might well take the form of positive feedback on skills that have nothing to do with traditional professional competencies. In the final example, Niklas Svensson, a journalist at the tabloid Expressen known among other things for his interviews with politicians during parliamentary election campaigns (see Olausson 2017), appraises a media appearance by Ebba Busch Thor, leader of the Christian Democratic Party. More precisely, he applauds Busch Thor's appearance on Så ska det låta!, a popular prime-time television show on Swedish public service television, based on the Irish format The Lyrics Board, in which celebrities compete in an entertaining music quiz and perform on stage: 


\begin{tabular}{|l|l|}
\hline $\begin{array}{l}\text { Smart move by @buschebba to appear on } \\
\text { \#SåSkaDetLåta, Wouldn't surprise me if the } \\
\text { Christian Democrats gain a few points in the } \\
\text { next poll. 5 Feb 2017 }\end{array}$ & $\begin{array}{l}\text { In the initial tweet, journalist Niklas Svensson } \\
\text { praises Busch Thor's appearance from a polit- } \\
\text { ical marketing perspective }\end{array}$ \\
\hline @niklassvensson it's worth a try anyway :-) & $\begin{array}{l}\text { Svensson's tweet generates a humorous re- } \\
\text { sponse from Ebba Busch Thor: }\end{array}$ \\
\hline $\begin{array}{l}\text { @buschebba Fantastic singing, to say it again } \\
\text { le }\end{array}$ & $\begin{array}{l}\text { Reply from Svensson, who changes the topic } \\
\text { and instead delivers positive feedback on } \\
\text { Busch Thor's vocal performance, together with } \\
\text { a "thumbs up" symbol }\end{array}$ \\
\hline @niklassvensson thanks :-) & Positive and friendly reply from Busch Thor \\
\hline
\end{tabular}

Table 3: Transboundary interaction as mutual acknowledgement

\section{A Critical Theoretical Understanding of Transboundary Interaction between Politicians, Journalists and PR Practitioners}

To begin with, a critical theoretical perspective on the above-exemplified forms of interaction should be viewed as a critical response to the transparency thesis, which is associated with network theory (Castells 2009; 2011a; 2011b; Cardoso 2012). Network theory stresses, among other things, digital technology's ability to generate symmetric relations through a "culture of sharing" (Cardoso 2012). In the digital age, networked collaboration is becoming customary, with transparency as a key value and practice. An active open stance on the part of individuals, institutions, organisations and businesses, towards each other and towards society as a whole, is supposedly rewarded in the form of more competitive businesses and more confident consumers/citizens. According to Manuel Castells $(2011 \mathrm{~b}, 11)$ "transparency is no longer just a [...] virtue [...] but an imperative tactic if the aim is to stay clear of disrepute". Thus, this theoretical perspective seems to suggest that cross-professional relations which were previously restricted to hidden back-stage activities and spaces are now, due to the cultural power of networked 'sharing', forced out into the daylight, thereby becoming a (transparent) front-stage phenomenon (cf. Thompson 1995, 91-93). Twitter and other social media platforms are viewed as public stages from which actors/users disclose how the everyday relations between politicians, journalists and PR practitioners work 'in reality' like 'authentic' behind-the-scene documentaries.

Arguing against the network-theoretical perspective, however, one could also claim that the transboundary interaction on Twitter and other social media sites rather exemplifies a dysfunctional public sphere (cf. Fuchs 2014b). To begin with, whether previously hidden connections across professional boundaries really are now being accessed by wider audiences is difficult to verify. Some backstage relations probably do stay backstage, and never come out into the light of social media. In this regard, a study by Berglez (2016) suggests that Twitter seems instead to generate backstagelike conversations, i.e. light versions of off-the-record discourse centred around joking and relaxed chatting, which do not preclude the existence of more sensitive and 'secret' backstage conversations in offline contexts.

A second critical point is that the ideological normalisation of very close relations between actors who ought to maintain a certain distance might lead to cynicism (Sloterdijk 1987), apathy and further distrust of society's central institutions among the public (Rothstein 2005). Even if the everyday chatting across professional borders 
does not lead to cronyism, or other abuses of power, it might nevertheless pave the way for a legitimation crisis (Habermas 1988).

The important background to the above-formulated criticism of network-theoretical thinking is the assumption that transboundary interaction on Twitter or other social media sites involves a neoliberalisation of cross-professional relations, ${ }^{4}$ i.e. that the activities transcending the boundaries between professional fields more or less stem from "market-based logic and practices, especially logics of market determinism, commodification, individualization, competitive ritual and self-interest" (Phelan 2014, 57). In this context, the idea is not to exchange network-technological determinism (Van Dijk 1999) for historical materialist orthodoxy. On the one hand, the transboundary interactions witness to fundamental sides of human communication, such as the need for sociability and humour. This makes it difficult to say that ironic joking between a PR practitioner and a journalist on Twitter somehow corresponds to neoliberal capitalism and the conflict between capital and labour. But, on the other hand, capitalism still has something to do with it. Sean Phelan's (2014) perspective of "neoliberalized logic" seems relevant in this case, suggesting that what potentially makes neoliberal processes so powerful is that they might be produced "by social institutions and agents that do not see themselves as neoliberal" (Phelan 2014, 33), in situations that seem very remote from macro-oriented economic and material processes in society. Consequently, everyday exchanges of jokes and likes across professional fields on social media might be viewed as banal (Billig 1995), 'innocent' forms of interaction, and thus insignificant for social research. However, such banal discourse might have a serious impact by serving as a lubricant for macro-oriented structural changes involving the labour market (the expansion and intensification of a marketised 'team-switching' culture) as well as the ongoing 'PR-ization of politics' (the convergence of politics and PR) and churnalism (the convergence of journalism and PR).

\subsection{How is Transboundary Interaction Connected to Neoliberal Processes?}

The point of departure is the 'economic' dimension of the socio-technological conventions of everyday social media use. As is the case with performances on social media in general, transboundary interaction exemplifies how "the 'reflexive project of the self' (Giddens) has become an explicit form of labour under post-Fordist capital in the form of 'self-branding'" (Hearn 2008, 197; Marwick 2013). In this respect, Fairclough's (1995; 2009) media-theoretical concept, conversationalism, is important, suggesting that the above-exemplified creative use and/or combining of discourses, genres and styles for the sake of impression management takes place within a networked market where actors primarily sell ideas or products; including trying to establish a fan-base, seeking to attract voters, and so on (Davis 2013). However, what seems peculiar about the above-exemplified politics-media-PR interplay is that the self-branding practices

${ }^{4}$ In this respect, according to political economists, network theory becomes a barrier to enlightenment. Network theory tends to highlight the role of the Internet and social media for the generation of dynamic, social transformation and individual empowerment. But, simultaneously, what becomes repressed is the framing of digital technology by market capitalism and its power relations (Van Dijk 1999). Ampuja and Koivisto (2014) suggest that Manuel Castells's work "offers a version of information society theory that is compatible with the neoliberal restructuration of capitalist societies" (Ibid., 456; cf. Holmes 2006, 9; Fuchs 2012). Amongst other things, Castells tends to highlight subjectivities whose networked relations and practices are mainly occupied with innovation and entrepreneurship (Ampuja and Koivisto 2014), thus fitting with the ideal subject of late capitalism (Boltanski and Chiapello 2005). 
also spill over to and thus involve cross-professional interaction that might seem ethically dubious. Consequently, when a politician is praising a journalist for his brilliant ability to cover domestic affairs (the Löö/Oksanen example), or when a conservative ex-politician/PR-practitioner and a news media producer of a leftist tabloid reveal their television habits to their Twitter audiences (the Persson/Olsson example), the actors involved seem to calculate that taking part in the buddy-buddy-oriented exchange across professional borders is more advantageous for their careers than avoiding it.

As a suggestion, the existence of transboundary activities needs to be understood in relation to the cultural pressure (or allure, depending on the person) to avoid traditional professionalism and its "impersonal, rationalized procedures" (Holmes 2006, 7), and instead to embrace the vivid self-branding language of social media culture. The use of social skills, empathy, humour, self-irony, etc. in promoting yourself as well as your organisation is the universal language of social media, applied by "everyone" irrespective of professional belonging (Marwick 2013). Hence, the above-exemplified cross-professional exchange is stimulated by and/or drawn into Twitter's common market-oriented reward system about what should be considered good or bad examples of professionalism. According to this reward system, success is not necessarily synonymous with how well one represents or defends one's professional culture in relation to other professional cultures, but concerns who you are as a person (funny, powerful, charismatic, etc.). ${ }^{5}$ The individualisation of the construction of professional identities in society (Rosa 2003) which, as a consequence, is thriving on social media (cf. Olausson 2017) is characterised by discourse in which the actors/users are not necessarily being something (a journalist, politician, PR practitioner) but rather working as something (as a journalist...). This, in turn, facilitates personal/informal rather than formal/strict relationships across professional boundaries (Rosa 2003, 19).

At the same time, traditional boundary work (Revers 2014) is still important and highly alive on Twitter and other social media sites. Whether through single posts/statuses or in the context of cross-professional interaction, journalists and politicians do also clearly articulate their different competencies, roles and duties in society (see Olausson 2017); journalists do also demonstrate professional integrity in relation to the PR business (Fredriksson and Johansson 2014); and so forth. Therefore, one can reasonably assume that transboundary activities tend to be 'compensated' and thus balanced by boundary work and vice versa (Berglez 2016). This involves the users' ability, in a Foucauldian sense, to 'discipline' their entire public persona as such, i.e. to perfectly combine professional/formal and personal/private communication, including 'barely professional' and 'verging on inappropriate' contributions. Below, different variants of how boundary and transboundary interaction might be combined are illustrated, imagined as consecutive situations of social media activity:

${ }^{5}$ This kind of market-oriented reward system might then either harmonise with or go against existing ethical guidelines for social media use among the different professional groups. While some employers and organisations encourage their staff to practice self-branding with few restrictions, others might apply more restrictive policies (see Vaast and Kaganer 2013). There might also be differences between the professional groups, in which unrestricted selfbranding comes more naturally for people in the PR business than for politicians and journalists. 
(A) TRANSBOUNDARY-TRANSBOUNDARY-TRANSBOUNDARY-TRANSBOUNDARY-TRANSBOUNDARY...

(B) BOUNDARY-BOUNDARY-BOUNDARY-BOUNDARY-BOUNDARY ...

(C) TRANSBOUNDARY-BOUNDARY-BOUNDARY-TRANSBOUNDARY-BOUNDARY...

Politicians and journalists have the most to lose from too much transboundary interaction $(A)^{6}$, as this might have a negative impact on their professional authority and status. Option (B), only engaging in boundary work, i.e. 'You're a politician and I'm a journalist and let's remain professional', exemplifies the ethically safe way of interacting across professional borders, and also tends to provide the actors with authority and symbolic capital (cf. Bourdieu 2003/1972) within their own professional group as well as among 'traditionally minded' citizens. However, it might also become associated with excessive strictness and thus constitute bad self-marketing. What remains for achieving self-promotional 'success' then is $(C)$, i.e. recurrent switching and balancing between boundary work and transboundary interaction, which needs to be understood in relation to neoliberal economics' "flexibilization of production and the labor processes" (Ampuja and Koivisto 2014, 456). In societies where subjects must adapt with increasing rapidity to changing material and economic conditions of capitalism, flexible personalities (Holmes 2006) characterised by 'code switching' ability are highly necessary. In this respect, public and semi-public figures belonging to the politics-media-PR sector can potentially serve as socio-economic role models on Twitter and/or other social media sites. Clinging solely to old professional boundaries is anti-flexible, while playing, challenging or even breaking them, i.e. intermingling across professional fields with ease and treating digital space as a single common market, generates high flexibility scores. This is indicative of strong communicative entrepreneurship (see Ampuja and Koivisto 2014): the ability to be dynamic, vital, and creative all the time. ${ }^{7}$

It might be thought that transboundary interaction is not a problem as long as the relations between these professional groups are still dominated by traditional boundary work. There is no harm, so to speak, in the occasional ironic joke or personal chat, assuming that users always make sure to bounce back to their basic professional identities and duties. Even if this seems rational somehow, the weakness of this kind of reasoning is the assumption that professional relationships and identities will remain intact instead of silently changing. In accordance with Hegel's statement about the owl of Minerva, which spreads its wings only at dusk, the effects that ever more micro-acts of the transboundary kind might generate in the future may not become clear to us until afterwards. To use another neoliberal term, an expansion of transboundary interaction on social media risks paving the way for fundamentally deregulated relations between politicians, journalists and PR practitioners in society.

\section{Concluding Comments}

Social media research was originally dominated by approaches embedded in networktheoretical optimism about the democratic potentials of digital media technology (see Mandiberg 2012). But, as the social media landscape gradually became colonised by

${ }^{6}$ See Footnote 5.

${ }^{7}$ A parallel demand is always to be ready to jump back and forth between employment and unemployment (see, for example, Edström and Ladendorf 2013). See also Footnote 4. 
market capitalist interests and logic, involving ownership concentration, issues of surveillance/aggregated content, branding culture, and so on, the need for critical research became obvious (Fuchs 2014a; 2014b; Marwick 2013). In this complementary contribution to a critical understanding of social media/Twitter, it is argued that everyday social intermingling between politicians, journalists and PR practitioners - referred to as transboundary interaction - exemplify an emerging 'neoliberalisation' of crossprofessional relations. Some might argue that the only thing that could possibly suppress further normalisation of 'too cosy' social intermingling would be deep, far-reaching crises in these relations. For example, the election in 2016 of businessman and Republican Donald Trump as President of the United States has, for good reason, been met with criticism and cultural fear among many groups, both in the US and abroad. However, at least one thing that might be considered positive about Trump's presidency is the 'rebirth' of antagonistic relations (Mouffe 2005) between the journalistic guild and the US government, in which potentially blurred boundaries have been replaced by interactions in which the professional groups' respective roles appear distinctly. Furthermore, the recent discussions about a post-truth society and the expansion of 'fake news' seem to pave the way for a renewed interest in what constitutes trustworthy and valid knowledge. This, in turn, might generate greater awareness of the problem of churnalism and the blurring of boundaries between editorial and PRbased information. It is highly questionable, however, whether such temporal professional and public 'awakenings' can make a radical difference in the longer run. This is because, despite potential national variations, the market-driven hybridisation and convergence of the politics-media-PR sector should primarily be viewed as a structural phenomenon, which is intertwined with an entire socio-material and economic system (global capitalism). In other words, a critique of transboundary interaction in the case of politics, media and PR needs to be combined with a questioning of the entire global capitalist system of which this kind of interaction is an integral part, culturally and materially.

The transboundary kind of interaction discussed in this article ought to be further tested and studied through systematic empirical studies. Such studies could follow social media users over time, or focus on the complex relations between boundary and transboundary work. Furthermore, there is need for comparisons across nation-states. Are transboundary activities particularly prevalent in Western countries with relatively small populations, such as Sweden, which are characterised by small distances between elites? To better understand how cross-professional relations work and develop in the social media landscape, it is possible to survey and interview professionals who frequently engage in transboundary interaction online. Citizen studies also seem relevant, i.e. examining ordinary users' observations of transboundary interactions and their views on it from a democratic point of view. How do different groups of citizens react to the exchange of 'cosy tweets' between politicians, journalists and PR practitioners? 'Thumbs up' or angry smileys?

\section{References}

Allern, Sigurd. 2011. PR, Politics and Democracy. Central European Journal of Communication 4 (1): 123-137.

Ampuja, Marko and Juha Koivisto. 2014. From "Post-Industrial" to "Network Society" and Beyond: The Political Conjunctures and Current Crisis of Information Society Theory. tripleC: Communication, Capitalism \& Critique. Open Access Journal for a Global Sustainable Information Society 12 (2): 447-463. Accessed 02 January 2018. http://www.triple-c.at/index.php/tripleC/article/view/568 
Berglez, Peter. 2016. Few-to-Many Communication: Public Figures' Self-Promotion on Twitter through "Joint Performances" in Small Networked Constellations. Annales. Series Historia et Sociologia. 26 (1): 171-184.

Berglez, Peter. 2006. The Materiality of Media Discourse. On Capitalism and Journalistic Modes of Writing [Doctoral thesis]. Örebro: Örebro Studies in Media and Communication 4.

Billig, Michael. 1995. Banal Nationalism. Los Angeles: Sage.

Boltanski, Luc and Eve Chiapello. 2005. The New Spirit of Capitalism. International Journal of Politics, Culture, and Society 18 (3): 161-188.

Bourdieu, Pierre. 2003/1972. Outline of a Theory of Practice. Cambridge: Cambridge University Press.

Cardoso, Gustavo. 2012. Networked Life World: Four Dimensions of the Cultures of Networked Belonging. Observatorio (OBS*) Journal, Special Issue: 197-205.

Castells, Manuel. 2011a. A Network Theory of Power. International Journal of Communication 5: 773-787.

Castells, Manuel. 2011b. Democracy in the Age of Internet. Journal of Contemporary Culture 6: $96-103$.

Castells, Manuel. 2009. Communication Power. Oxford: Oxford University Press.

Chadwick, Andrew. 2013. The Hybrid Media System: Politics and Power. Oxford: Oxford University Press.

Chadwick, Andrew and Simon Collister. 2014. Boundary-Drawing Power and the Renewal of Professional News Organizations: The Case of The Guardian and the Edward Snowden National Security Agency Leak. International Journal of Communication 8: 2420-2441.

Crawford, Kate. 2009. Following You: Disciplines of Listening in Social Media. Continuum: Journal of Media \& Cultural Studies 23 (4): 525-535.

Davis, Aeron. 2013. Promotional Cultures: The Rise and Spread of Advertising, Public Relations, Marketing and Branding. Cambridge: Polity Press.

Davis, Aeron. 2009. Journalist-Source Relations, Mediated Reflexivity and the Politics of Politics. Journalism Studies 10 (2): 204-219.

Deuze, Mark. 2007. Media Work. Cambridge: Polity Press.

Edström, Maria and Martina Ladendorf. 2012. Freelance Journalists as a Flexible Workforce in Media Industries. Journalism Practice 6 (5-6): 711-721.

Ekman, Mattias and Andreas Widholm. 2015. Politicians and Media Producers. Current Trajectories in the Relation Between Journalists and Politicians in the Age of Social Media. Journalism Practice 9 (1): 78-91.

Fairclough, Norman. 2009. A Dialectical-Relational Approach to Critical Discourse Analysis in Social Research. In Methods of Critical Discourse Analysis, edited by Ruth Wodak and Michael Meyer, 162-186. Los Angeles: Sage.

Fairclough, Norman. 1995. Media Discourse. London: Arnold.

Fredriksson, Magnus and Bengt Johansson. 2014. The Dynamics of Professional Identity. Why Journalists View Journalists Working with PR as a Threat to Journalism. Journalism Practice 8 (5): 585-595.

Fuchs, Christian. 2017. Raymond Williams' Communicative Materialism. European Journal of Culture Studies 20 (6): 744-762.

Fuchs, Christian. 2014a. Social Media: A Critical Introduction. Los Angeles: Sage.

Fuchs, Christian. 2014b. Social Media and the Public Sphere. tripleC: Communication, Capitalism \& Critique. Open Access Journal for a Global Sustainable Information Society 12 (1): 57-101. Accessed 02 January 2018. http://www.triple-c.at/index.php/tripleC/article/view/552

Fuchs, Christian. 2012. Some Reflections on Manuel Castells's Book Networks of Outrage and Hope. Social Movements in the Internet Age. tripleC: Communication, Capitalism \& Critique. Open Access Journal for a Global Sustainable Information Society 10 (2): 775797. Accessed 02 January 2018. http://www.triple-c.at/index.php/tripleC/article/view/459 
Gans, Herbert J. 1979. Deciding What's News: A Study of CBS Evening News, NBC Nightly News, Newsweek and Time. New York: Pantheon.

Garsten, Christina, Bo Rothstein and Stefan Svallfors. 2015. Makt utan mandat: de policyprofessionella i svensk politik. Stockholm: Dialogos Förlag.

Habermas, Jürgen. 1989/1962. The Structural Transformation of the Public Sphere: An Inquiry into a Category of Bourgeois Society. Cambridge, MA: MIT Press.

Habermas, Jürgen. 1988. Legitimation Crisis. Cambridge: Polity Press.

Hearn, Alison. 2008. Meat, Mask, Burden: Probing the Contours of the Branded "Self". Journal of Consumer Culture 8 (2): 197-217.

Hallin, Daniel and Paolo Mancini. 2004. Comparing Media Systems: Three Models of Media and Politics. Cambridge: Cambridge University Press.

Hedman, Ulrika. 2015. J-Tweeters. Pointing Towards a New Set of Professional Practices and Norms in Journalism. Digital Journalism 3 (2): 279-297.

Hedman, Ulrika and Monica Djerf-Pierre. 2013. The Social Journalist: Embracing the Social Media Life or Creating a New Digital Divide? Digital Journalism 1 (3): 368-385.

Holmes, Brian. 2006. The Flexible Personality: For a New Cultural Critique. Transversal [online journal]. Accessed 5 February 2017. http://eipcp.net/transversal/1106/holmes/en/print

Holton, Avery E. and Seth C. Lewis. 2011. Journalists, Social Media, and the Use of Humor on Twitter. The Electronic Journal of Communication 21 (1-2): 1-19.

Jackson, Daniel and Kevin Moloney. 2016. Inside Churnalism: PR, Journalism and Power Relationships in Flux. Journalism Studies 17 (6): 763-780.

Larsson, Larsåke. 2002. 'Journalists and Politicians: A Relationship Requiring Maneuvering Space. Journalism Studies 3 (1): 21-33.

Lewis, Justin, Andrew Williams and Bob Franklin. 2008. A Compromised Fourth Estate? UK News Journalism, Public Relations and News Sources. Journalism Studies 9 (1): 1-20.

Macnamara, Jim. 2016. The Continuing Convergence of Journalism and PR: New Insights for Ethical Practice from a Three-Country Study of Senior Practitioners. Journalism \& Mass Communication Quarterly 93 (1): 118-141.

Mandiberg, Michael. Ed. 2012. The Social Media Reader. New York: New York University Press.

Marwick, Alice. 2013. Status Update: Celebrity, Publicity \& Branding in the Social Media Age. New Haven: Yale University Press.

Marwick, Alice and boyd, danah. 2011. To See and Be Seen: Celebrity Practice on Twitter. Convergence 17 (2): 139-158.

Mouffe, Chantal. 2005. On the Political: Thinking in Action. New York: Routledge.

O'Donnell, Penny, Lawrie Zion and Merryn Sherwood. 2016. Where Do Journalists Go After Newsroom Job Cuts? Journalism Practice 10 (1): 35-51.

Olausson, Ulrika. 2017. The Reinvented Journalist: The Discursive Construction of Professional Identity on Twitter. Digital Journalism 5 (1): 61-81.

Papacharissi, Zizi. 2011. Conclusions: A Networked Self. In A Networked Self. Identity, Community, and Culture on Social Network Sites, edited by Zizi Papacharissi, 304-318. New York: Routledge.

Phelan, Sean. 2014. Neoliberalism, Media and the Political. New York: Palgrave.

Reese, Stephen D. 2016. The New Geography of Journalism Research: Levels and Spaces. Digital Journalism 4 (7): 816-826.

Revers, Matthias. 2014. Journalistic Professionalism as Performance and Boundary Work: Source Relations at the State House. Journalism 15 (1): 37-52.

Rosa, Hartmut. 2003. Social Acceleration: Ethical and Political Consequences of a Desynchronized High-Speed Society. Constellations 10 (1): 1-33.

Rothstein, Bo. 2005. Social Traps and the Problem of Trust. Cambridge: Cambridge University Press. 
Schohaus, Birte, Marcel Broersma and Huub Wijfjes. 2016. Negotiation Games: Play Metaphors in the Journalist-Source Relationship Between Political PR and Talk shows. Journalism Practice 11 (8): 925-941.

Sloterdijk, Peter. 1987. Critique of Cynical Reason. Minneapolis: University of Minnesota Press.

Strömbäck, Jesper and Lars W. Nord. 2006. Do Politicians Lead the Tango? A Study of the Relationship between Swedish Journalists and their Political Sources in the Context of Election Campaigns. International Journal of Press/Politics 21 (2): 147-164.

Thompson, John B. 1995. The Media and Modernity: A Social Theory of the Media. Cambridge: Polity Press.

Tyllström, Anna. 2010. PR-konsultbranschens framväxt i Sverige. In Företag och medier, edited by Josef Pallas and Lars Strannegård, 169-191. Malmö: Liber.

Vaast, Emmanuelle and Kaganer, Evgeny. 2013. Social Media Affordances and Governance in the Workplace: An Examination of Organizational Policies. Journal of Computer-Mediated Communication 19 (1): 78-101.

Van Dijk, Jan A.G.M.1999. The One-Dimensional Network Society of Manuel Castells. New Media \& Society 1 (1): 127-138.

Vobič, Igor, Alem Maksuti and Tomaž Deželan. 2016. Who Leads the Twitter Tango? Studying the Journalist-Politician Relationship in Slovenia Through Twitter Conversations. Digital Journalism 9 (5): 1134-1154.

Waters, Richard D., Natalie T. J. Tindall and Timothy S. Morton. 2010. Media Catching and the Journalist-Public Relations Practitioner Relationship: How Social Media are Changing the Practice of Media Relations. Journal of Public Relations Research 22 (3): 241-264.

Wendt, Maria. 2012. Politik som spektakel: Almedalen, mediemakten och den svenska demokratin. Stockholm: Atlas.

Williams, Raymond. 1980. Problems in Materialism and Culture: Selected Essays. London: Verso and NLB.

Yardi, Sarita and boyd, danah. 2010. Dynamic Debates: An Analysis of Group Polarization over time in Twitter. Bulletin of Science, Technology \& Society 30 (5): 316-327.

Östberg, Kjell. 2013. Almedalen: Så skapades en politikens marknadsplats - Ett vittnessemin-arium om Almedalsveckan som politisk arena. Stockholm: Södertörns högskola, Institutionen för historia och samtidsstudier, Samtidshistoriska institutet.

\section{About the Author}

Peter Berglez is Professor of Media and Communication Studies at Jönköping University, Sweden. His critical theoretical research primarily focuses on the relation between globalization and journalism and environmental/sustainable communication. Examples of publications are his book Global Journalism: Theory and Practice (2013) and the volume Sustainable journalism: Integrating the environmental, social, and economic challenges of journalism (2017), coedited with U. Olausson and M. Ots. 